\title{
Sulcal Depth-Position Profile Is a Genetically Mediated Neuroscientific Trait: Description and Characterization in the Central Sulcus
}

\author{
D. Reese McKay, ${ }^{1,2,3}$ Peter Kochunov, ${ }^{4}$ Matthew D. Cykowski, ${ }^{5}$ Jack W. Kent Jr, ${ }^{6}$ Angela R. Laird, ${ }^{7}$ Jack L. Lancaster, ${ }^{1}$ \\ John Blangero, ${ }^{5}$ David C. Glahn, ${ }^{2,3}$ and Peter T. Fox ${ }^{1,8}$ \\ ${ }^{1}$ Research Imaging Institute, University of Texas Health Science Center San Antonio, San Antonio, Texas 78229, ${ }^{2}$ Department of Psychiatry, Yale University \\ School of Medicine, New Haven, Connecticut 06511, ${ }^{3}$ Olin Neuropsychiatry Research Center, Institute of Living, Hartford Hospital, Hartford, Connecticut \\ 06106, ${ }^{4}$ Maryland Psychiatric Research Center, Department of Psychiatry, University of Maryland School of Medicine, Baltimore, Maryland 21201, \\ ${ }^{5}$ Department of Genetics, Texas Biomedical Research Institute, San Antonio, Texas 78245, ${ }^{6}$ Department of Pathology, University of Oklahoma Health \\ Sciences Center, Oklahoma City, Oklahoma 73104, ${ }^{7}$ Department of Physics, Florida International University, Miami, Florida 33199, and ${ }^{8}$ South Texas \\ Veterans Health System, San Antonio, Texas 78229
}

Genetic and environmental influences on brain morphology were assessed in an extended-pedigree design by extracting depth-position profiles (DPP) of the central sulcus (CS). T1-weighted magnetic resonance images were used to measure CS length and depth in 467 human subjects from 35 extended families. Three primary forms of DPPs were observed. The most prevalent form, present in $70 \%$ of subjects, was bimodal, with peaks near hand and mouth regions. Trimodal and unimodal configurations accounted for 15 and $8 \%$, respectively. Genetic control accounted for 56 and $66 \%$ of between-subject variance in average CS depth and length, respectively, and was not significantly influenced by environmental factors. Genetic control over CS depth ranged from 1 to $50 \%$ across the DPP. Areas of peak heritability occurred at locations corresponding to hand and mouth areas. Left and right analogous CS depth measurements were strongly pleiotropic. Shared genetic influence lessened as the distance between depth measurements was increased. We argue that DPPs are powerful phenotypes that should inform genetic influence of more complex brain regions and contribute to gene discovery efforts.

\section{Introduction}

During gyrencephalic brain development, the cerebral cortex takes on a predictable folding pattern. The rolandic or central sulcus (CS) is a particularly identifiable landmark. With primary sensory and motor cortices on the caudal and rostral banks, respectively, the CS and surrounding region is perhaps the most thoroughly characterized portion of the cortex. From the first demonstrations of somatotopy in stimulate and observe paradigms (Horsley and Schafer, 1888) to mapping neural correlates of fine motor skill (Amunts et al., 1997; Rotte et al., 2002; Witt et al., 2008), the perirolandic region has been assessed with systemslevel neuroscience paradigms for over a century. Despite a wealth of information on the coupling of structure and function, little

\footnotetext{
Received April 16, 2013; revised July 30, 2013; accepted Aug. 27, 2013.

Author contributions: D.R.M., P.K., J.W.K., A.R.L., J.L.L., J.B., D.C.G., and P.T.F. designed research; D.R.M., P.K., J.W.K., A.R.L., J.L.L., J.B., and D.C.G. performed research; J.W.K., and A.R.L. contributed unpublished reagents/ analytic tools; D.R.M. and P.K. analyzed data; D.R.M. and P.T.F. wrote the paper.

This work was supported by the National Institutes of Health: the National Center for Research Resources (UL 1RR025767 to the Institute for Integration of Medicine and Science at the University of Texas Health Science Center at San Antonio), the National Institute of Mental Health (MH078143 to D.C.G., MH078111 and MH059490 to J.B., MH083824 to D.C.G., and J.B.; MH074457 to P.T.F. and A.R.L.), and the National Institute of Biomedical Imaging and Bioengineering (EB006395 and EB015611 to P.K.).

The authors declare no competing financial interests.

Correspondence should be addressed to D. Reese McKay, Department of Psychiatry, Yale School of Medicine, 300 George Street, New Haven, CT 06511. E-mail: david.mckay@yale.edu.

DOI:10.1523/JNEUROSCI.1616-13.2013

Copyright $\odot 2013$ the authors $\quad 0270-6474 / 13 / 3315618-08 \$ 15.00 / 0$
}

is known of causal neurobiologic determinants of cortical morphology.

While the effects of specific environmental conditions are well described (Amunts et al., 1997; Hammond, 2002; Sun et al., 2012), it is theorized that genetic factors play a strong role. Sulci are more similar in twins than unrelated pairs (Lohmann et al., 1999). More directly related to genes, a shortened extent of the dorsal CS is characteristic of Williams syndrome (Galaburda et al., 2001), which results from the deletion of a small section of chromosome 7 (Francke, 1999). Additionally, expression of the DNA-associated protein Trnpl varies by region and promotes radial or tangential cortical expansion with low or high expression levels, respectively (Stahl et al., 2013). Together, these studies provide strong circumstantial evidence that the CS is influenced by genetic factors; however, the degree of genetic control is unknown. Establishing the heritability of CS features motivates the use of cortical folds as phenotypes in the search for genetic roots of neuroanatomy. Because sulcation is likely linked to other brain traits (Van Essen, 1997; Toro and Burnod, 2005; Xu et al., 2010; Nie et al., 2012), the identification of genes that influence sulcal morphology would represent a significant neuroscientific advancement. To make progress toward this overarching goal, there is urgent need for fundamental neuroscientific traits that have been established in well understood brain structures.

Two large-scale neuroimaging initiatives - the Genetics of Brain Structure and Function study (GOBS) and the BrainMap 
database-were used to investigate the role of genetic factors in the established structure-function coupling of the CS. We treated CS depth as a continuous phenotype spanning the entire fundus by measuring its depth at 100 successive points, thus producing a depth-position profile (DPP). The functional importance of genetic influence was interpreted meta-analytically. We also tested for brain-behavior pleiotropy (shared genetic influence) using performance on a dextral speeded task. From these analyses, we propose the notion that the degree of genetic control of sulcal depth is an index of functional specialization.

In effort to provide foresight for future imaging-genetic studies, we also used DPPs to glean general principles from maps of shared genetic and environmental influences. Formally characterizing factors that influence the CS will better our understanding of the perirolandic region and should provide guidance for genetic investigations of less understood areas of the cortex.

\section{Materials and Methods}

Subjects. Studies using large extended pedigrees have multiple benefits compared with twin designs, including increased power to detect heritable effects, less confounding of genetic effects with shared environmental effects because of the inclusion of multiple households within pedigrees, and greater mathematical power to localize and identify causal quantitative trait loci (Blangero, 2004). In this study, we examined 467 MexicanAmerican individuals from 35 large extended pedigrees (average family size $=9$ people; range $=5-32$ ) who have participated in the GOBS study to date. Participants were $61 \%$ female, ranged in age from 19 to 85 years (mean $\pm \mathrm{SD}=47.7 \pm 13.4$ years) and were $>90 \%$ right-handed. Handedness was assessed with the Edinburgh handedness inventory (Oldfield, 1971). Individuals in this cohort have actively participated in genetics research for over 15 years and initially were randomly recruited with the constraints that they are of Mexican-American ancestry, part of a large family, and live within the San Antonio, TX region. In the current study, individuals were excluded for magnetic resonance imaging (MRI) contraindications, history of neurological illness, stroke or other major neurological event. All experiments were undertaken with the understanding and written consent of each subject on forms approved by the institutional review board at the University of Texas Health Science Center of San Antonio.

MR imaging. Imaging was performed using a Siemens $3 \mathrm{~T}$ Trio scanner and a multichannel phase array head coil. T1-weighted images of $800 \mu \mathrm{m}$ isotropic resolution were acquired using a retrospective motioncorrected protocol (Kochunov et al., 2006). Under this protocol, seven full-resolution volumes were acquired using a 3D TurboFLASH sequence with an adiabatic inversion magnetization preparation contrast pulse (scan parameters: TE/TR/TI $=3.04 / 2100 / 785 \mathrm{~ms}$, flip angle $=11^{\circ}$ ). These optimized parameters enabled uniform tissue contrast across the imaging volume.

Preprocessing. The procedure to prepare images for extraction of sulcal phenotypes consisted of the following steps: removal of nonbrain tissue (Smith, 2002), correction for spatial variations in intensity (Zhang et al., 2013), and global spatial normalization (Smith et al., 2004). Global spatial normalization was used to reduce intersubject variability in global brain size, shape, and orientation by spatially registering all images to a Talairach-compliant population-based template using a nine parameter, affine, linear transformation (Kochunov et al., 2002). This lessened the impact of highly heritable variability in brain volume, focusing subsequent genetic analyses on regional variance of sulcal structures rather than variance associated with whole brain size (Rogers et al., 2007; 2010; Kochunov et al., 2010). Last, all images were resliced to isotropic $800 \mu \mathrm{m}$ spacing using a 3D, 15 voxel wide sinc interpolation kernel.

Extraction of phenotypes. Images were imported into the BrainVISA database system (www.brainvisa.info) and processed with the sulcal extraction and identification pipeline (Mangin et al., 2004) and a freely available library of morphological tools (www.nitrc.org/projects/brainvisa_ext/; Kochunov et al., 2012). Sulcal structures were extracted as the medial surface between two adjacent gyral banks. The BrainVISA neural network-based

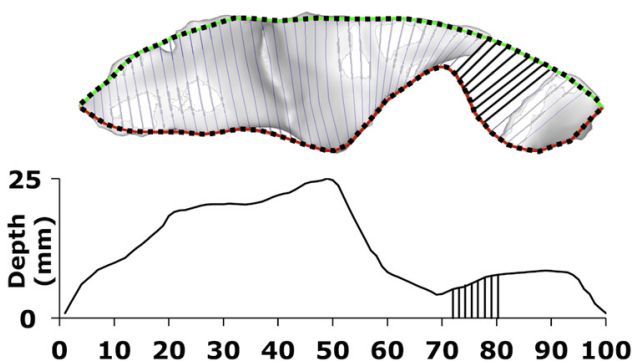

Figure 1. Quantifying sulcal depth. The top ridge curve (green/black line) was defined by the locations of the intersection between sulcal body and the exterior convex hull. Locations were then used to define a plane orthogonal to the top ridge curve and the sulcal body. The most distal coplanar point on the sulcal body defined a point on the bottom ridge (red/black line). Each of the 100 depth measurements down the sulcal mesh was calculated as the length of a curve that connected equidistant points on the top ridge and the fundus, thus constituting a DPP.

Table 1. Published studies employing fingertapping tasks used in the meta-analysis

\begin{tabular}{llc}
\hline Publication & Type of movement & \# of subjects \\
\hline Blinkenberg et al., 1996 & Fingertapping & 8 \\
Ramsey et al., 1996 & Fingertapping & 9 \\
Sadato et al., 1996 & Fingertapping & 10 \\
Joliot et al., 1998 & Fingertapping & 5 \\
Joliot et al., 1999 & Fingertapping & 8 \\
Gelnar et al., 1999 & Fingertapping & 8 \\
Gerardin et al., 2000 & Finger flexion/extension & 8 \\
Jäncke et al., 2000a & Fingertapping & 11 \\
Jäncke et al., 2000b & Button Press & 8 \\
Lutz et al., 2000 & Fingertapping & 10 \\
Indovina and Sanes, 2001 & Button press & 9 \\
Kuhtz-Buschbeck et al., 2003 & Fingertapping & 12 \\
Lerner et al., 2004 & Fingertapping & 10 \\
Wilson et al., 2004 & Finger movement & 10 \\
Aoki et al., 2005 & Fingertapping & 10 \\
De Luca et al., 2005 & Fingertapping & 14 \\
Denslow et al., 2005 & Fingertapping & 11 \\
Rounis et al., 2005 & Fingertapping & 8 \\
Yoo et al., 2005 & Fingertapping & 10 \\
Lehéricy et al., 2006 & Fingertapping & 12 \\
\hline
\end{tabular}

Activations from 191 subjects contributed to the localization of fingertapping.

sulcal identification algorithm was used to identify and label CS. For primary sulci, such as the CS, this process is $>95 \%$ accurate (Rivière et al., 2002); labeling in each subject was reviewed by two skilled neuroanatomists. Mislabels were manually corrected. A 2D ribbon representing each CS was extracted for subsequent measurements.

CS depth was calculated as the path length on the sinuous sulcal surface from the outermost (Fig. 1, green/black line) to the innermost (red/ black line) boundary of the sulcus. This method (Kochunov et al., 2010) is computationally improved but theoretically analogous to that used in our prior report on the CS (Cykowski et al., 2008). One hundred path lengths of equidistant spacing on a single CS constituted a DPP. Average CS depth was calculated by taking the mean of the 100 depths from each hemisphere (hemispheric phenotypes; Table 1) or the mean of the 200 depths from each brain (global phenotypes; Table 1).

Depth was measured at 100 points down each subjects' CS; however, we excluded the first and last 10 measurements when conducting DPPbased genetic analyses (see Figs. 3-5). This exclusion criteria was applied to make alignment and comparison to results reported in Talairach space more reliable, as the CS often branches near the Sylvian and interhemispheric fissures, which caused spikes in depth measurements. In our previous research, scaling of individual sulci based on overall length provided a better overlap in regional sulcal features in both humans and primates (Cykowski et al., 2008; Hopkins et al., 2010). The approximate 
range of our sampling in Talairach space was $25<\mathbf{z}<70$, which corresponded to points 100:1 in CS space. That is, location 1 (Talairach $\mathbf{z} \approx 70$ ) was nearest to the interhemispheric fissure and location 100 (Talairach $\mathbf{z} \approx 25$ ) was nearest to the Sylvian fissure.

Quantitative genetic analyses. Variance components methods, as implemented in the Sequential Oligogenic Linkage Analysis Routines (SOLAR) software package (Almasy and Blangero, 1998), were used for all genetic analyses (http://www.nitrc.org/projects/se_linux/).

Heritability $\left(\boldsymbol{h}^{2}\right)$ is the proportion of total phenotypic variance $\left(\sigma_{\mathrm{p}}^{2}\right)$ that is accounted for by additive genetic factors, and is assessed by contrasting the observed phenotypic covariance matrix with the covariance matrix predicted by kinship $\left(\boldsymbol{h}^{2}=\sigma^{2}{ }_{G} / \sigma^{2}{ }_{p}\right)$, where $\sigma^{2}{ }_{G}$ is the genetic variance due to additive genetic factors, and $\sigma_{\mathrm{E}}^{2}$ is the variance due to environmental effects. High heritability indicates that the covariance of a phenotype is greater among more closely related (genetically similar) individuals.

Significance of heritability was tested by comparing the $\log _{\mathrm{e}}$ likelihood of the model in which $\sigma^{2}{ }_{\mathrm{G}}$ is constrained to zero with that of a model in which $\sigma^{2}{ }_{G}$ is estimated. Twice the difference between the two $\log _{e}$ likelihoods of these models yields a test statistic, which is asymptotically distributed as a $1 / 2: 1 / 2$ mixture of a $\boldsymbol{\chi}^{2}$ variable and a point mass at zero. Before testing for the significance of heritability, phenotype values for each individual were adjusted for a series of covariates (age, sex, age ${ }^{2}$, age $\times$ sex interaction, age ${ }^{2} \times$ sex interaction, and handedness). We used a polygenic model that estimated the influence of specific variables (additive genetic variation, covariates, and random unidentified environmental effects) to calculate heritability and its significance ( $p$ value) for variation of CS traits with a $5 \%$ false discovery rate (FDR) to correct for multiple comparisons.

Bivariate genetic correlation analyses were performed to decompose phenotypic correlations $\left(\rho_{\mathrm{P}}\right)$ between two traits into genetic $\left(\rho_{\mathrm{G}}\right)$ and environmental $\left(\rho_{\mathrm{E}}\right)$ correlations, accounting for kinship: $\rho_{\mathrm{P}}=\rho_{\mathrm{G}} V\left(\boldsymbol{h}^{2}{ }_{A} \boldsymbol{h}^{2}{ }_{\boldsymbol{B}}\right)+\rho_{\mathrm{E}} V\left[\left(1-\boldsymbol{h}^{2}{ }_{\boldsymbol{A}}\right)\left(1-\boldsymbol{h}^{2}{ }_{\boldsymbol{B}}\right)\right]$, where $\boldsymbol{h}^{2}{ }_{\boldsymbol{A}}$ and $\boldsymbol{h}^{2}{ }_{\boldsymbol{B}}$ are the heritability estimates for traits $\boldsymbol{A}$ and $\boldsymbol{B}$. The magnitude of $\rho_{\mathrm{G}}$ is a measurement of pleiotropy, or shared genetic variance between traits; $\rho_{\mathrm{E}}$ is the variance shared due to environmental effects (Almasy et al., 1997). Such assessments were made possible by the presence of multiple households within the extended pedigree.

The significance of genetic and environmental correlation was tested by comparing the log likelihood for two restricted models (with either $\rho_{\mathrm{G}}$ or $\rho_{\mathrm{E}}$ constrained to zero) against the log likelihood for the model in which these parameters were estimated. A significant genetic correlation ( $p \leq 0.05,5 \%$ FDR) is evidence for pleiotropy, suggesting that a gene or set of genes jointly influences both phenotypes (Comuzzie et al., 1997).

Bilateral influence of genes or set of genes was characterized by performing bivariate correlation analysis on analogous depth measurements from the left and right hemispheres. That is, the depth at location " $x$ " of the left CS was tested with location " $x$ " of the right CS across all CS depth measurements. Genetic and environmental correlation coefficients were then plotted as functions of sulcal position.

Functional probes. Functional interpretations were sought by identifying estimates of sensorimotor regions previously associated with fingertapping and oral movements. Our extended pedigree investigations do not include task-based functional imaging. Instead, we performed a literature search for published groupwise peak-activation coordinates using the BrainMap database (www.brainmap.org) of functional MRI and positron emission tomography studies. A published meta-analysis on the functional correlates of fingertapping (Witt et al., 2008) provided a foundation for the purposes of the current report. Activations were primarily in the left hemisphere because all experiments were conducted on righthanded subjects instructed to perform tasks with their right hand. A meta-analysis of oral movement had not been reported, but the BrainMap database contained sufficient data to drive a meta-analysis. Oral movement studies included tongue movement, lip pursing, and smiling. For both fingertapping and oral movement searches were limited to Brodmann Area (BA) 4, 3, 1, and 2.

Activation likelihood estimation (ALE) methods were applied to the previously published activation coordinates to quantify the dimensions of and signal within predicted activation regions (Laird et al., 2005; Eick-
Table 2. Published studies employing oral movement tasks used in the meta-analysis

\begin{tabular}{llc}
\hline Publication & Type of oral movement & \# of subjects \\
\hline Bookheimer et al., 2000 & Tongue movement & 8 \\
Lotze et al., 2000 & Lip pursing & 7 \\
Rotte et al., 2002 & Lip pursing and tongue movement & 9 \\
Fesl et al., 2003 & Tongue movement & 11 \\
Gerardin et al., 2003 & Lip extension & 7 \\
Hesselmann et al., 2004 & Lip pursing and tongue movement & 6 \\
Leslie et al., 2004 & Smiling & 15 \\
Martin et al., 2004 & Tongue movement & 14 \\
Watanabe et al., 2004 & Tongue movement & 24 \\
Hennenlotter et al., 2005 & Smiling & 12 \\
Dapretto et al., 2006 & Facial imitation & 10 \\
Brown et al., 2008 & Lip pucker and tongue movement & 16 \\
\hline
\end{tabular}

Activations from 139 subjects contributed to the localization of oral movement.

hoff et al., 2009). Fingertapping and oral movement regions were identified using a modified ALE method (GingerALE; Eickhoff et al., 2009). Quantitative estimates of between-subject and between-template variability were empirically determined to explicitly model the spatial uncertainty associated with each activation coordinate. Activation coordinates were permutated to test for the above-chance clustering between experiments, resulting in a random-effects method of statistical inference. Therefore, ALE clusters were not unduly influenced by any single study (Table 2).

Cogent mapping from coordinate to DPP space was achieved in a two-step process: First, activation clusters were honed to the CS by limiting the BrainMap search to BA 4, 3, 1, and 2. Second, groupwise primary axis decomposition of the CS strongly aligned with the Talairach $\mathbf{z}$-axis, therefore the activation clusters were approximated by the $\mathbf{z}$-coordinate extent of ALE hand and mouth clusters. For a related application of this approach, see Cykowski et al. (2008).

Brain-behavior pleiotropy. Shared genetic influence of performance on a dextral speeded process and the fingertapping area of the left DPP was also analyzed. The speeded process task was a continuous pairs test designed to assess motor and sensory processing speed, working memory, and attention (Cornblatt and Malhotra, 2001). Subjects were briefly presented with a group of three shapes that appeared on a screen, quickly followed by another group of three shapes. This continued for 200 trials and lasted a maximum of $5 \mathrm{~min}$ in all. Subjects were told to press the space bar each time the same group of shapes appeared twice in a row, which occurred a total of 70 times for each subject. Average reaction time for true positives was the behavioral metric that was used to test for pleiotropy with CS depth.

Pleiotropy by distance. Shared genetic influence as a function of distance between CS depth measurements was assessed by performing bivariate correlation analysis on depths ranging from 1 to 50 points away from one another, which corresponded to $\sim 0.8-30 \mathrm{~mm}$. This distance range ensured adequate sampling over the entire sulcus. The average genetic and environmental correlation coefficients for each distance were then plotted and fit with polynomial functions. The distance range of 50 measurements $(\sim 30 \mathrm{~mm})$ was chosen so that each of the 100 points was sampled at least twice.

\section{Results}

\section{DPPs}

Three primary forms of DPPs were observed (Fig. 2A). The dominant profile, present in $70 \%$ of subjects, was bimodal. The superior portion of the DPPs was more variable than the inferior portion. One subject had a split CS composed of two entirely separate sulci. Trimodal and unimodal configurations accounted for 15 and $8 \%$ of subjects' configurations, respectively. Although the majority of the observed sulci had bimodal DPPs, the superior portion of the bimodal configurations differed drastically by subject (Fig. 2B). For this reason, aligning sulci by peak or trough 

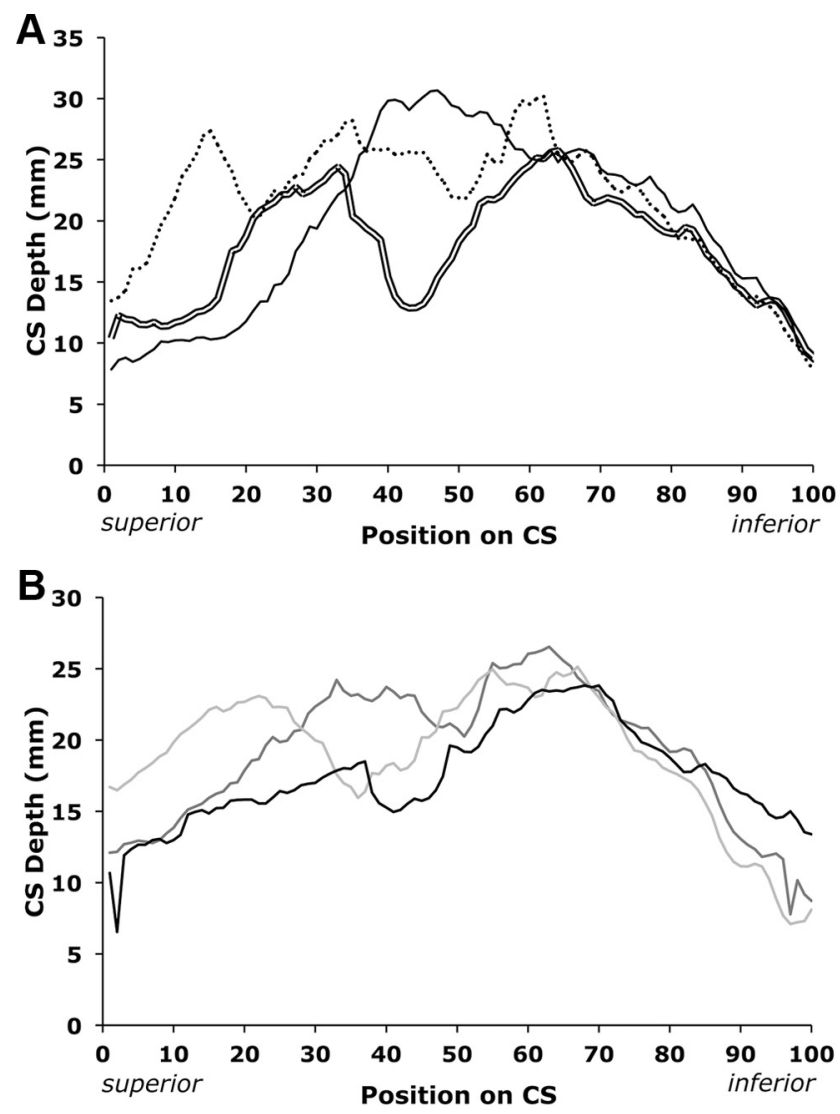

Figure 2. DPPs from individual subjects. $A$, Data from three subjects demonstrates how DPPs varied: bimodal (double line), trimodal (dotted line), and unimodal (solid line). $\boldsymbol{B}$, Data from three subjects demonstrates how bimodal DPPs varied. Note spikes in first and last 10 measurements.

would have introduced subjective observer dependence and inconsistently altered the position of traits with respect to the surrounding sensorimotor cortex. Additionally, the inferior peaks of bimodal configurations had some degree of natural alignment in native DPP space. Because there were three varying modal configurations within the extended pedigrees, mean depth by position should be interpreted cautiously and is displayed purely for comparison to previous reports (Fig. 3, light gray trace; Cykowski et al., 2008; Hopkins et al., 2010).

\section{Heritability of global and hemispheric phenotypes}

CS length and depth were significantly heritable globally. Length was more heritable in the right hemisphere; depth was more heritable in the left (Table 1). Age, age ${ }^{2}$, sex, age $\times$ sex interaction, age $^{2} \times$ sex interaction, and handedness were included as covariates in all analyses. However, specific contributions of these covariates to hemispheric asymmetries are outside the scope of the current report and have been reported previously (Cykowski et al., 2008; Hopkins et al., 2010). All of the covariates combined to account for $3-8 \%$ of the phenotypic variance in all traits. Age, age $^{2}$, sex, and their interactions were significant in genetic analyses of depth, but were only significant for length in the left hemisphere. Handedness did not account for a significant portion of variance in any of the analyses. Variations of peak location, peak depth, and number of peaks were uniformly nonheritable traits (Table 3).

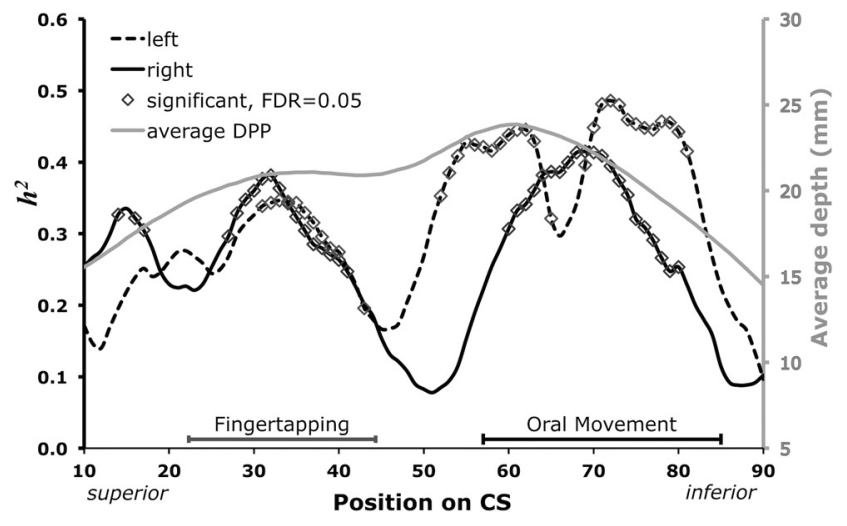

Figure 3. Genetic influence of DPP structure and function. $C S \boldsymbol{h}^{2}$-DPPs from each hemisphere (left, black dashed trace; right, black solid trace; primary $y$-axis). For reference to previously published reports, the mean DPP across all subjects is also plotted by position (gray trace; secondary $y$-axis). Predicted activation areas for fingertapping (gray segment) and oral movement (black segment) are plotted just above the $x$-axis.

Table 3. Heritability of global and hemispheric phenotypes

\begin{tabular}{llll}
\hline CS trait & $\boldsymbol{h}^{\boldsymbol{2}} \pm$ SE & $p$ value & Covariate variance $^{a}$ \\
\hline Average depth (left and right) & $0.56 \pm 0.11$ & $2.9 \times 10^{-8}$ & $8 \%$ \\
Average length (left and right) & $0.66 \pm 0.12$ & $1.2 \times 10^{-9}$ & $4 \%$ \\
Left average depth & $0.59 \pm 0.09$ & $10^{-7}$ & $6 \%$ \\
Right average depth & $0.41 \pm 0.11$ & $10^{-5}$ & $6 \%$ \\
Left average length & $0.47 \pm 0.12$ & $5 \times 10^{-6}$ & $4 \%$ \\
Right average length & $0.60 \pm 0.12$ & $3 \times 10^{-7}$ & $3 \%$ \\
\hline
\end{tabular}

Global phenotypes were calculated by averaging $C S$ measurements from both hemispheres; hemispheric phenotypes were calculated by averaging measurements from each hemisphere separately. ${ }^{a}$ Variance explained by demographic covariates: age, age ${ }^{2}$, sex, age $\times$ sex, and age ${ }^{2} \times$ sex, which were included in all genetic analyses.

\section{Genetic and functional analyses of DPPs}

Heritability of DPPs ( $\boldsymbol{h}^{2}$-DPPs) varied by position and hemisphere (Fig. 3). The values comprising the three peaks of each profile were significant $\left(\mathrm{P}_{\text {avg }}=7 \mathrm{E}-4,80 / 160\right.$ positions $)$ after correcting for multiple comparisons. In the superior portion of the CS (Fig. 3), the significant portions of the left and right $\boldsymbol{h}^{2}$-DPPs were quite similar. However, three points in the right reached significance $(\mathbf{x}=14,16,17)$ whereas the left did not contain significantly heritable depth in this region. The $\boldsymbol{h}^{2}$-DPPs differed more so in the inferior portion (Fig. 3). Specifically, the left had a trough that separated two prominent peaks $(52 \leq \mathbf{x} \leq 63$ and $70 \leq \mathbf{x} \leq 81)$, while the right had one uninterrupted peak $(60 \leq$ $\mathbf{x} \leq 80$ ). In general, the $\boldsymbol{h}^{2}$-DPPs were qualitatively similar, although the right had an additional peak superiorly while the left had an additional peak inferiorly.

The locations of the peaks of the $\boldsymbol{h}^{2}$-DPPs were adjacent to specialized functional areas. The predominant superior portion of the $\boldsymbol{h}^{2}$-DPPs was encompassed by the predicted fingertapping area. Fingertapping activation mapped to $25 \leq \mathbf{x} \leq 47$ of the DPP (Fig. 3), which corresponded to Talairach $z$-coordinates of $\sim 51 \leq \mathbf{z} \leq 61$. Nineteen published studies contributed to the mapping of this area. Oral movement activation mapped to $57 \leq$ $\mathbf{x} \leq 85$ of the DPP (Fig. 3), which corresponded to Talairach $z$-coordinates of $\sim 31 \leq \mathbf{x} \leq 45$. The predominant inferior portion of the $\boldsymbol{h}^{2}$-DPPs coincided with the oral movement area. Twelve published studies contributed to the mapping of this area, involving lip pursing, tongue movement, or smiling. In general, lip pursing activation coordinates were superior to tongue movement coordinates, but there was overlap and the ALE analysis did not split the predicted region of interest (ROI) into separate clusters. Interestingly, the peaks of each DPP were not pleiotropic 


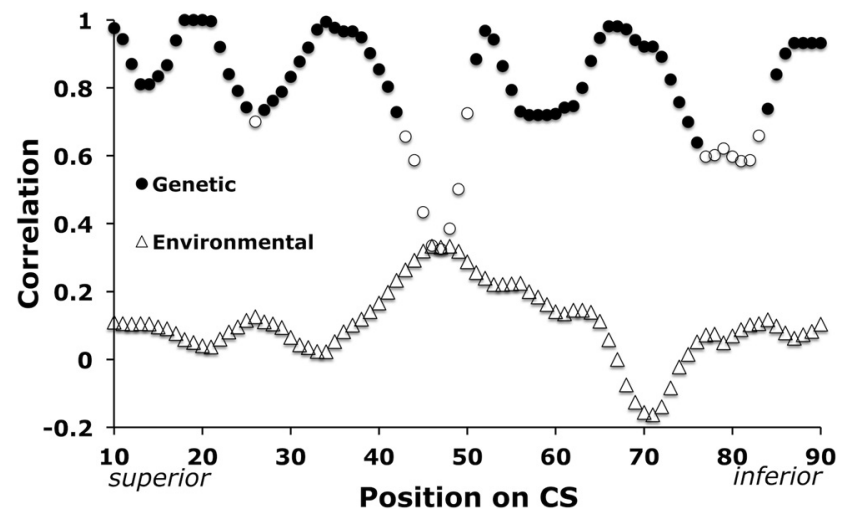

Figure 4. Correlation of left and right DPP analogs. Common genetic and environmental influence of left and right analogous CS depth measurements. Correlation coefficients are plotted as a function of position on the profile. Shaded circles were significant, indicating pleiotropy $\left(\rho_{\mathrm{G}, \text { avg }}=0.88, \mathrm{p}_{\mathrm{avg}}=0.009, \mathrm{FDR}=0.05\right)$. No environmental correlation coefficients reached significance $\left(\rho_{\mathrm{E}, \text { avg }}=0.10, \mathrm{p}_{\mathrm{avg}}=0.17 ; \triangle\right)$.

with one another, suggesting that different gene sets contribute to depth in the hand and mouth regions.

Significant behavior-brain pleiotropy was found between average reaction time on a dextral speeded process task and the fingertapping area of the left DPP. Average reaction time across all subjects was $580 \mathrm{~ms}$; average number of true positives was 57 of a possible 70. Pleiotropy was significant using two variations of CS depth. In one, the structural metric was average depth in the fingertapping area of the left DPP $\left(\rho_{\mathrm{G}}=0.5, p=0.05\right)$. In the other variation, the structural metric was depth at the location of peak heritability within the fingertapping area of the DPP $\left(\rho_{\mathrm{G}}=\right.$ $0.6, p=0.02$ ).

Left and right analogous CS depth measurements were strongly pleiotropic (Fig. 4). More specifically, evidence indicated that common genes or sets of genes influenced depth at position $\mathrm{x}$ of the left DPP and position $\mathrm{x}$ of the right DPP (Fig. 4, $\rho_{\mathrm{G}, \text { avg }}=0.88, \mathrm{p}_{\mathrm{avg}}=0.009$, filled circles). No position shared significant environmental influence $\left(\rho_{\mathrm{E}, \text { avg }}=0.10, \mathrm{p}_{\mathrm{avg}}=0.17\right.$, open triangles). Nonsignificant genetic correlations (open circles) clustered near the middle of the DPP $(43 \leq \mathrm{x} \leq 50)$ and in the inferior portion of the oral movement area $(77 \leq \mathrm{x} \leq 83)$.

The distance between CS depth measurements strongly affected bivariate correlation analyses (Fig. 5) as the degree of shared genetic control fell off as a function of distance. Common genetic influence (filled circles) was best fit by a third-degree polynomial; common environmental influence (open triangles) was best fit by a fourth-degree polynomial. Common genetic influence reached a steady correlation value of $\sim 0.4$ at a distance of 30 sampling points, while common environmental influence continued to slope downward and was negative beyond a distance of $\sim 40$ sampling points.

\section{Discussion}

This experiment provides direct evidence that DPPs capture patterns of genetic influence on CS morphology. Heritability of CS depth varied as a function of position. The most heritable portions of the sulcus corresponded to specialized functions (fingertapping and oral movements). In addition, we found significant genetic correlation between performance on a speeded dextral task and CS depth within the finger movement region. Together, these findings strongly suggest that sulcal depth is influenced by genetic factors that reflect established functional organization of the cortex. Going forward, this motivates the use of DPPs to

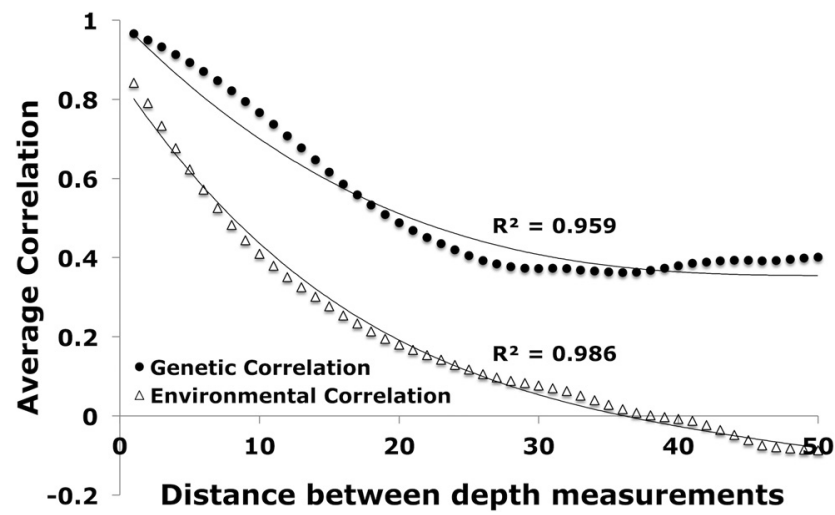

Figure 5. Genetic and environmental correlation by distance. Common genetic and environmental influence are plotted as functions of distance between CS depth measurements. Average correlation coefficients were plotted for depths that ranged from 1 to 50 points away from one another, which corresponded to $\sim 0.8-30 \mathrm{~mm}$.

characterize genetic underpinnings of brain structure and function.

\section{Relation to prior sulcal research}

Lohmann et al. (1999) first indicated the influence of genetic factors on sulcal variability. However, this study included only 10 twin pairs without a control group and involved no formal genetic testing-co-twins were compared, then pairs were "shuffled" and the same groups of subjects were compared as unrelated pairs. It was concluded that sulcal similarity increased with sulcal depth significantly more so in monozygotic twins than unrelated pairs (Lohmann et al., 1999). Figure 3 may indicate that $\boldsymbol{h}^{2}$-DPP peaks correspond to sulcal depth peaks in apparent support of Lohmann's conclusion. However, in light of Figure 2, it is quite clear that individual subject data are far too variable to glean Lohmann's conclusion from Figure 3's average depth trace. Moreover, correlation of depth versus $\boldsymbol{h}^{2}$ in the current sample was not convincing $\left(\boldsymbol{R}^{2}=0.2\right.$; data not shown $)$.

Algorithms for computing sulcal similarity across subjects have proven useful for group-level analysis (Lohmann et al., 2008; Im et al., 2010, 2011), but do not yield meaningful neuroscientific traits on a per subject basis. Use of such algorithms in small twin samples suggest that sulcal features, such as depth peaks or troughs, are ideal for comparing or normalizing variance across subjects, and that landmarks in the beds of sulci inform an organizational framework of the brain. However, such landmarks are described quantitatively for each subject by DPPs and therefore directly translate to traits without statistical inference. Furthermore, DPPs describe the pith of sulcal morphology vis-àvis surrounding brain structure and more readily lend to investigations of how genes influence the brain.

Regis et al. (2005) proposed that a plis de passage, or hidden bridge of cortex partially buried within sulci, is biologically important, and that a sulcus that has a plis de passage should be split at the plis and treated as two separate components or roots. This is particularly relevant to the central sulcus, as its bed is traversed by the plis de passage de frontopariétal moyen (Broca, 1888). Our results strongly recapitulate Regis' postulate, as $\boldsymbol{h}^{2}$-DPPs were bifid with peaks that corresponded to separable hand and mouth regions.

\section{Lateralization of function}

The prominent trough in the inferior portion of the left $\boldsymbol{h}^{2}$-DPP separates two inferior peaks, while the right $\boldsymbol{h}^{2}$-DPP only has one. 
We suggest that this asymmetry reflects increased genetic influence related to BA 6 in the left hemisphere. The presence of BA 6 in this portion of the CS was first noted by Brodmann (2006) himself:

"Area 4 does not quite reach the lower end of the (central) sulcus; in many cases it stops $2-3 \mathrm{~cm}$ higher in the depths of the sulcus. Areas 4 and 6 undergo a gradual transition such that the identification of the line of transition is purely subjective and can only be determined from numerous individual brains."

These statements are especially relevant to the current report's focus on variance related to the depth of the sulcus in 467 brains. We suggest the left $\boldsymbol{h}^{2}$-DPP in this portion of the CS is a reflection of genetically driven functional specialization in conjunction with the lateralization of speech (Damasio and Geschwind, 1984; Devlin and Watkins, 2007). Kell et al. (2011) postulated that lateralization of speech starts in the left sensory cortex and is maintained in the motor cortex. Findings indicated that the articulatory somatosensory cortex was one of only two regions that showed a strong left lateralization during speech preparation. Herein, this was one of only two regions that did not share bilateral genetic influence (Fig. 4). Our meta-analytic oral movement ROI did not draw upon speech activations, therefore we can only speculate on this matter. However, a genetic component of lateralized speech is supported circumstantially by our finding that the localization of oral movements corresponds to Brodmann's cytoarchitectonic split and Kell's theory of left somatosensorybased speech lateralization.

\section{Implications for the field of imaging genetics}

From genetic analysis of an extremely identifiable and well understood feature of the brain, we sought general rules that may apply to less understood brain regions. For this purpose, we describe three broad ranging principles. First, a "distance rule" suggests that topographically distant cortical traits are genetically distant, while traits that are near one another share a greater degree of genetic influence. Second, hemispheric counterparts of the CS were strongly pleiotropic (and not under common environmental influence) despite heavily lateralized dexterity within our sample ( $>90 \%$ right-handed). This suggests that genetic influence follows a "symmetry rule" in that a feature in one hemisphere is likely under the control of the same genes or sets of genes as the analogous feature in the opposite hemisphere. Thirdly, we propose that heritability peaks along DPPs are indices of genetically controlled functional specialization, even within the same cytoarchitectonic regions (BA 4, 3, 1, 2). This suggests that genetic influence follows a "functional specialization rule." Furthermore, genetic and environmental effects within these regions should be more detectable than in other functional regions by the homuncular principle that highly specialized regions are allocated more cortical area. Setting forth hypotheses derived from and tested within brain traits where neuroscientific principles are commonly regarded will aid the study of function and dysfunction in less understood brain regions.

The symmetry rule strongly recapitulates a key aspects of the first cortical atlas constructed entirely from genetic information (Chen et al., 2012). Therein, 5124 vertexwise measurements of cortical surface area were genetically clustered, yielding a genetic correlation map where hemispheric symmetry is a predominant feature. This implies that lateralization may take place by other means, such as gene penetrance, expression, or untested environmental influence.

The distance rule may represent systems-level ramifications of the proto-map hypothesis, which states that developmental pro- jections from the ventricular zone map neurons to predefined layers of cytoarchitectonic areas (Rakic, 1988). Broadening Rakic's theory from neurons to sulci implies that proliferative units are also responsible for the brain's distinctive and species-specific macroscopic architecture. If true, image-based DPPs are an extremely powerful phenotype in that the characterization of ontogenetic factors, as described by Rakic, are beyond the resolution of MRI and too invasive for in vivo human research, while sulci are detectable as early as the 12th week of gestation (Zhang et al., 2013) with innocuous MRI procedures.

Phenotypes are often tested in abundance without regard to hypotheses or structure-function relationships. An alternative approach is selecting, modeling, and evaluating potential phenotypes based on the ability to test neuroscience driven hypotheses. Though seemingly apparent, this notion is a drastic deviation from modern high-profile methods, such as testing every voxel in an image for genome-wide association. Not only does such a broad net increase type 1 error, it also undermines a century of neuroscience research with a moot question: do genetic variants influence image voxels? Because the actions of genes are largely unknown, phenotypes should represent neuroscientific truth, as we presume, instead of an arbitrary aspect of image processing. The notion that heritability peaks are indices of genetically controlled functional specialization is a strong indication that findings from 25 years of functional imaging research should be used to help define traits for gene discovery. From a genetics standpoint, traits that represent genetic clusters [e.g., the Chen subdivisions (Chen, 2012) and hand/mouth regions of DPPs] garner greater statistical power for gene identification studies and have a fundamental neuroscientific component from which we can further our understanding of how genes influence neuroscientific traits.

\section{Application to other sulci}

Phenotypes from DPPs of sulci that are long and rarely interrupted will likely yield optimal results. Specifically, the collateral, callosal, calcarine, parieto-occipital, and central sulci are $>90 \%$ likely to be continuous (Ono et al., 1990). Strong association with adjacent BAs is also characteristic of these sulci. In contrast, the precentral and inferior temporal sulci are almost always interrupted, which would complicate the comparison of DPPs across subjects.

\section{Gene discovery}

The current study does not provide information concerning the identity of the causal genes that influence the brain. However, it does provide substantial evidence that there are genes involved in the development of the CS and that image-based DPPs are sensitive to genetic mediation. Identification of these genes will provide an important vantage point for understanding the brain's intrinsic genetic architecture.

\section{References}

Almasy L, Blangero J (1998) Multipoint quantitative-trait linkage analysis in general pedigrees. Am J Hum Genet 62:1198-1211. CrossRef Medline

Almasy L, Dyer TD, Blangero J (1997) Bivariate quantitative trait linkage analysis: pleiotropy versus co-incident linkages. Genet Epidemiol 14:953958. CrossRef Medline

Amunts K, Schlaug G, Jäncke L, Steinmetz H, Schleicher A, Dabringhaus A, Zilles K (1997) Motor cortex and hand motor skills: structural compliance in the human brain. Hum Brain Mapp 5:206-215. CrossRef Medline

Aoki T, Tsuda H, Takasawa M, Osaki Y, Oku N, Hatazawa J, Kinoshita H (2005) The effect of tapping finger and mode differences on cortical and 
subcortical activities: a PET study. Exp Brain Res 160:375-383. CrossRef Medline

Blangero J (2004) Localization and identification of human quantitative trait loci: king harvest has surely come. Curr Opin Genet Dev 14:233-240. CrossRef Medline

Blinkenberg M, Bonde C, Holm S, Svarer C, Andersen J, Paulson OB, Law I (1996) Rate dependence of regional cerebral activation during performance of a repetitive motor task: a PET study. J Cereb Blood Flow Metab 16:794-803. Medline

Bookheimer SY, Zeffiro TA, Blaxton TA, Gaillard PW, Theodore WH (2000) Activation of language cortex with automatic speech tasks. Neurology 55:1151-1157. CrossRef Medline

Broca P (1888) Mémoires d'anthropologie. Paris: Reinwald.

Brodmann K (2006) The description of individual maps. In: Localization in the cerebral cortex (Garey LJ, trans), pp 111-112. New York: Springer Science + Business Media. (Original work published 1909)

Brown S, Ngan E, Liotti M (2008) A larynx area in the human motor cortex. Cereb Cortex 18:837-845. CrossRef Medline

Chen CH, Gutierrez ED, Thompson W, Panizzon MS, Jernigan TL, Eyler LT, Fennema-Notestine C, Jak AJ, Neale MC, Franz CE, Lyons MJ, Grant MD, Fischl B, Seidman LJ, Tsuang MT, Kremen WS, Dale AM (2012) Hierarchical genetic organization of human cortical surface area. Science 335: 1634-1636. CrossRef Medline

Comuzzie AG, Mahaney MC, Almasy L, Dyer TD, Blangero J (1997) Exploiting pleiotropy to map genes for oligogenic phenotypes using extended pedigree data. Genet Epidemiol 14:975-980. CrossRef Medline

Cornblatt BA, Malhotra AK (2001) Impaired attention as an endophenotype for molecular genetic studies of schizophrenia. Am J Med Genet 105:11-15. CrossRef Medline

Cykowski MD, Coulon O, Kochunov PV, Amunts K, Lancaster JL, Laird AR, Glahn DC, Fox PT (2008) The central sulcus: an observer-independent characterization of sulcal landmarks and depth asymmetry. Cereb Cortex 18:1999-2009. CrossRef Medline

Damasio AR, Geschwind N (1984) The neural basis of language. Annu Rev Neurosci 7:127-147. CrossRef Medline

Dapretto M, Davies MS, Pfeifer JH, Scott AA, Sigman M, Bookheimer SY, Iacoboni M (2006) Understanding emotions in others: mirror neuron dysfunction in children with autism spectrum disorders. Nat Neurosci 9:28-30. CrossRef Medline

De Luca M, Smith S, De Stefano N, Federico A, Matthews PM (2005) Blood oxygenation level-dependent contrast resting state networks are relevant to functional activity in the neocortical sensorimotor system. Exp Brain Res 167:587-594. CrossRef Medline

Denslow S, Lomarev M, George MS, Bohning DE (2005) Cortical and subcortical brain effects of transcranial magnetic stimulation (TMS)-induced movement: an interleaved TMS/functional magnetic resonance imaging study. Biol Psychiatry 57:752-760. CrossRef Medline

Devlin JT, Watkins KE (2007) Stimulating language: insights from TMS. Brain 130:610-622. CrossRef Medline

Eickhoff SB, Laird AR, Grefkes C, Wang LE, Zilles K, Fox PT (2009) Coordinate-based activation likelihood estimation meta-analysis of neuroimaging data: a random-effects approach based on empirical estimates of spatial uncertainty. Hum Brain Mapp 30:2907-2926. CrossRef Medline

Fesl G, Moriggl B, Schmid UD, Naidich TP, Herholz K, Yousry TA (2003) Inferior central sulcus: variations of anatomy and function on the example of the motor tongue area. Neuroimage 20:601-610. CrossRef Medline

Francke U (1999) Williams-Beuren syndrome: genes and mechanisms. Hum Mol Genet 8:1947-1954. CrossRef Medline

Galaburda AM, Schmitt JE, Atlas SW, Eliez S, Bellugi U, Reiss AL (2001) Dorsal forebrain anomaly in Williams syndrome. Arch Neurol 58:18651869. CrossRef Medline

Gelnar PA, Krauss BR, Sheehe PR, Szeverenyi NM, Apkarian AV (1999) A comparative fMRI study of cortical representations for thermal painful, vibrotactile, and motor performance tasks. Neuroimage 10:460-482. CrossRef Medline

Gerardin E, Sirigu A, Lehéricy S, Poline JB, Gaymard B, Marsault C, Agid Y, Le Bihan D (2000) Partially overlapping neural networks for real and imagined hand movements. Cereb Cortex 10:1093-1104. CrossRef Medline

Gerardin E, Lehéricy S, Pochon JB, Tézenas du Montcel S, Mangin JF, Poupon F, Agid Y, Le Bihan D, Marsault C (2003) Foot, hand, face and eye representation in the human striatum. Cereb Cortex 13:162-169. CrossRef Medline
Hammond G (2002) Correlates of human handedness in primary motor cortex: a review and hypothesis. Neurosci Biobehav Rev 26:285-292. CrossRef Medline

Hennenlotter A, Schroeder U, Erhard P, Castrop F, Haslinger B, Stoecker D, Lange KW, Ceballos-Baumann AO (2005) A common neural basis for receptive and expressive communication of pleasant facial affect. Neuroimage 26:581-591. CrossRef Medline

Hesselmann V, Sorger B, Lasek K, Guntinas-Lichius O, Krug B, Sturm V, Goebel R, Lackner K (2004) Discriminating the cortical representation sites of tongue and up movement by functional MRI. Brain Topogr 16: 159-167. Medline

Hopkins WD, Coulon O, Mangin JF (2010) Observer-independent characterization of sulcal landmarks and depth asymmetry in the central sulcus of the chimpanzee brain. Neuroscience 171:544-551. CrossRef Medline

Horsley V, Schafer EA (1888) A record of experiments upon the functions of the cerebral cortex. Phil Trans Roy Soc Lond B Biol Sci 179:1-45.

Im K, Jo HJ, Mangin JF, Evans AC, Kim SI, Lee JM (2010) Spatial distribution of deep sulcal landmarks and hemispherical asymmetry on the cortical surface. Cereb Cortex 20:602-611. CrossRef Medline

Im K, Pienaar R, Lee JM, Seong JK, Choi YY, Lee KH, Grant PE (2011) Quantitative comparison and analysis of sulcal patterns using sulcal graph matching: a twin study. Neuroimage 57:1077-1086. CrossRef Medline

Indovina I, Sanes JN (2001) Combined visual attention and finger movement effects on human brain representations. Exp Brain Res 140:265279. CrossRef Medline

Jäncke L, Loose R, Lutz K, Specht K, Shah NJ (2000a) Cortical activations during paced finger-tapping applying visual and auditory pacing stimuli. Brain Res Cogn Brain Res 10:51-66. CrossRef Medline

Jäncke L, Peters M, Himmelbach M, Nösselt T, Shah J, Steinmetz H (2000b) fMRI study of bimanual coordination. Neuropsychologia 38:164-174. CrossRef Medline

Joliot M, Crivello F, Badier JM, Diallo B, Tzourio N, Mazoyer B (1998) Anatomical congruence of metabolic and electromagnetic activation signals during a self-paced motor task: a combined PET-MEG study. Neuroimage 7:337-351. CrossRef Medline

Joliot M, Papathanassiou D, Mellet E, Quinton O, Mazoyer N, Courtheoux P, Mazoyer B (1999) FMRI and PET of self-paced finger movement: comparison of intersubject stereotaxic averaged data. Neuroimage 10:430447. CrossRef Medline

Kell CA, Morillon B, Kouneiher F, Giraud AL (2011) Lateralization of speech production starts in sensory cortices-a possible sensory origin of cerebral left dominance for speech. Cereb Cortex 21:932-937. CrossRef Medline

Kochunov P, Lancaster J, Thompson P, Toga AW, Brewer P, Hardies J, Fox P (2002) An optimized individual target brain in the Talairach coordinate system. Neuroimage 17:922-927. CrossRef Medline

Kochunov P, Lancaster JL, Glahn DC, Purdy D, Laird AR, Gao F, Fox P (2006) Retrospective motion correction protocol for high-resolution anatomical MRI. Hum Brain Mapp 27:957-962. CrossRef Medline

Kochunov P, Glahn DC, Fox PT, Lancaster JL, Saleem K, Shelledy W, Zilles K, Thompson PM, Coulon O, Mangin JF, Blangero J, Rogers J (2010) Genetics of primary cerebral gyrification: heritability of length, depth and area of primary sulci in an extended pedigree of Papio baboons. Neuroimage 53:1126-1134. Medline

Kochunov P, Rogers W, Mangin JF, Lancaster J (2012) A library of cortical morphology analysis tools to study development, aging and genetics of cerebral cortex. Neuroinformatics 10:81-96. CrossRef Medline

Kuhtz-Buschbeck JP, Mahnkopf C, Holzknecht C, Siebner H, Ulmer S, Jansen O (2003) Effector-independent representations of simple and complex imagined finger movements: a combined fMRI and TMS study. Eur J Neurosci 18:3375-3387. CrossRef Medline

Laird AR, Fox PM, Price CJ, Glahn DC, Uecker AM, Lancaster JL, Turkeltaub PE, Kochunov P, Fox PT (2005) ALE meta-analysis: controlling the false discovery rate and performing statistical contrasts. Hum Brain Mapp 25:155-164. CrossRef Medline

Lehéricy S, Bardinet E, Tremblay L, Van de Moortele PF, Pochon JB, Dormont D, Kim DS, Yelnik J, Ugurbil K (2006) Motor control in basal ganglia circuits using fMRI and brain atlas approaches. Cereb Cortex 16:149-161. Medline

Lerner A, Shill H, Hanakawa T, Bushara K, Goldfine A, Hallett M (2004) Regional cerebral blood flow correlates of the severity of writer's cramp symptoms. Neuroimage 21:904-913. CrossRef Medline 
Leslie KR, Johnson-Frey SH, Grafton ST (2004) Functional imaging of face and hand imitation: towards a motor theory of empathy. Neuroimage 21:601-607. CrossRef Medline

Lohmann G, von Cramon DY, Steinmetz H (1999) Sulcal variability of twins. Cereb Cortex 9:754-763. CrossRef Medline

Lohmann G, von Cramon DY, Colchester AC (2008) Deep sulcal landmarks provide an organizing framework for human cortical folding. Cereb Cortex 18:1415-1420. CrossRef Medline

Lotze M, Seggewies G, Erb M, Grodd W, Birbaumer N (2000) The representation of articulation in the primary sensorimotor cortex. Neuroreport 11:2985-2989. CrossRef Medline

Lutz K, Specht K, Shah NJ, Jäncke L (2000) Tapping movements according to regular and irregular visual timing signals investigated with fMRI. Neuroreport 11:1301-1306. CrossRef Medline

Mangin JF, Rivière D, Cachia A, Duchesnay E, Cointepas Y, PapadopoulosOrfanos D, Scifo P, Ochiai T, Brunelle F, Régis J (2004) A framework to study the cortical folding patterns. Neuroimage 23 [Suppl 1]:S129-S138. Medline

Martin RE, MacIntosh BJ, Smith RC, Barr AM, Stevens TK, Gati JS, Menon RS (2004) Cerebral areas processing swallowing and tongue movement are overlapping but distinct: a functional magnetic resonance imaging study. J Neurophysiol 92:2428-2443. CrossRef Medline

Nie J, Guo L, Li K, Wang Y, Chen G, Li L, Chen H, Deng F, Jiang X, Zhang T, Huang L, Faraco C, Zhang D, Guo C, Yap PT, Hu X, Li G, Lv J, Yuan Y, Zhu D, et al. (2012) Axonal fiber terminations concentrate on gyri. Cereb Cortex 22:2831-2839. CrossRef Medline

Oldfield RC (1971) The assessment and analysis of handedness: the Edinburgh inventory. Neuropsychologia 9:97-113. CrossRef Medline

Ono M, Kubik S, Abernathey CD (1990) Classification of sulci. In: Atlas of the cerebral sulci, p. 14. Stuttgart: Georg Thieme Verlag.

Rakic P (1988) Specification of cerebral cortical areas. Science 241:170-176. CrossRef Medline

Ramsey NF, Kirkby BS, Van Gelderen P, Berman KF, Duyn JH, Frank JA, Mattay VS, Van Horn JD, Esposito G, Moonen CT, Weinberger DR (1996) Functional mapping of human sensorimotor cortex with 3D BOLD fMRI correlates highly with H2(15)O PET rCBF. J Cereb Blood Flow Metab 16:755-764. Medline

Régis J, Mangin J-F, Ochiai T, Vincent Frouin, Riviré D, Cachia A, Tamura M, Samson Y (2005) "Sulcal Root" generic model: a hypothesis to overcome the variability of the human cortex folding patterns. Neurol Med Chir 45:1-17. Medline

Rivière D, Mangin JF, Papadopoulos-Orfanos D, Martinez JM, Frouin V, Régis J (2002) Automatic recognition of cortical sulci of the human brain using a congregation of neural networks. Med Image Anal 6:77-92. CrossRef Medline

Rogers J, Kochunov P, Lancaster J, Shelledy W, Glahn D, Blangero J, Fox P (2007) Heritability of brain volume, surface area and shape: an MRI study in an extended pedigree of baboons. Hum Brain Mapp 28:576-583. CrossRef Medline

Rogers J, Kochunov P, Zilles K, Shelledy W, Lancaster J, Thompson P, Duggirala R, Blangero J, Fox PT, Glahn DC (2010) On the genetic architecture of cortical folding and brain volume in primates. Neuroimage 53: 1103-1108. CrossRef Medline
Rotte M, Kanowski M, Heinze HJ (2002) Functional magnetic resonance imaging for the evaluation of the motor system: primary and secondary brain areas in different motor tasks. Stereotact Funct Neurosurg 78:3-16. CrossRef Medline

Rounis E, Lee L, Siebner HR, Rowe JB, Friston KJ, Rothwell JC, Frackowiak RS (2005) Frequency specific changes in regional cerebral blood flow and motor system connectivity following rTMS to the primary motor cortex. Neuroimage 26:164-176. CrossRef Medline

Sadato N, Campbell G, Ibáñez V, Deiber M, Hallett M (1996) Complexity affects regional cerebral blood flow change during sequential finger movements. J Neurosci 16:2691-2700. Medline

Smith SM (2002) Fast robust automated brain extraction. Hum Brain Mapp 17:143-155. CrossRef Medline

Smith SM, Jenkinson M, Woolrich MW, Beckmann CF, Behrens TE, Johansen-Berg H, Bannister PR, De Luca M, Drobnjak I, Flitney DE, Niazy RK, Saunders J, Vickers J, Zhang Y, De Stefano N, Brady JM, Matthews PM (2004) Advances in functional and structural MR image analysis and implementation as FSL. Neuroimage 23 [Suppl 1]:S208-S219. Medline

Stahl R, Walcher T, De Juan Romero C, Pilz GA, Cappello S, Irmler M, Sanz-Aquela JM, Beckers J, Blum R, Borrell V, Götz M (2013) Trnpl regulates expansion and folding of the mammalian cerebral cortex by control of radial glial fate. Cell 153:535-549. CrossRef Medline

Sun ZY, Klöppel S, Rivière D, Perrot M, Frackowiak R, Siebner H, Mangin JF (2012) The effect of handedness on the shape of the central sulcus. Neuroimage 60:332-339. Medline

Toro R, Burnod Y (2005) A morphogenetic model for the development of cortical convolutions. Cereb Cortex 15:1900-1913. CrossRef Medline

Van Essen DC (1997) A tension-based theory of morphogenesis and compact wiring in the central nervous system. Nature 385:313-318. CrossRef Medline

Watanabe J, Sugiura M, Miura N, Watanabe Y, Maeda Y, Matsue Y, Kawashima R (2004) The human parietal cortex is involved in spatial processing of tongue movement-an fMRI study. Neuroimage 21:1289-1299. CrossRef Medline

Wilson SM, Saygin AP, Sereno MI, Iacoboni M (2004) Listening to speech activates motor areas involved in speech production. Nat Neurosci 7:701702. CrossRef Medline

Witt ST, Laird AR, Meyerand ME (2008) Functional neuroimaging correlates of finger-tapping task variations: an ALE meta-analysis. Neuroimage 42:343-356. CrossRef Medline

Xu G, Knutsen AK, Dikranian K, Kroenke CD, Bayly PV, Taber LA (2010) Axons pull on the brain, but tension does not drive cortical folding. J Biomech Eng 132:071013. CrossRef Medline

Yoo SS, Wei X, Dickey CC, Guttmann CR, Panych LP (2005) Long-term reproducibility analysis of fMRI using hand motor task. Int J Neurosci 115:55-77. CrossRef Medline

Zhang Z, Hou Z, Lin X, Teng G, Meng H, Zang F, Fang F, Liu S (2013) Development of the fetal cerebral cortex in the second trimester: assessment with 7T postmortem MR imaging. Am J Neuroradiol 34:1462-1467. CrossRef Medline 